with young June 14. They ran around me with dropping wings; Coot, two nests; June 14; Lesser Yellowlegs, downy young with narent, June 14; Black Tern, two nests, June 14 (1) 1 egg, (2) 3 eggs; and a third nest June 15,1 egg.

A $i$ Snowden I observed 125 Redwings and 11 Brewer's Blackbirds. Sparrows were much more abund- ant here than at Fishing Lake and some species more common than at Nipawin. In three full days I observed: Savannah Sparrows (22); LeConte's (39); Vesper (11 and nest with 4 eggs); Junco (2); Chipping Sparrow (2); Clay-colored (33); White-throated (2); Lincoln's (4); Swamp (3); Song (14 and two nests -4 eggs and 5 eggs).

\title{
Game Act Revised To Protect Hawks And Owls
}

In the June, 1960 issue of the Blue Jay we inserted a brief notice of the amendment to the Game Act offering further protection to hawks and owls. Members of our society have since asked us to publish the amendment in full.

Section 10 of the Game Act for the Province of Saskatchewan was amended March, 1960, to read as follows:

"(1) Subject to subsections (2) and (3), no person shall hunt, take, shoot at, wound or kill any game bird or any other bird that is wild by nature and in a state of nature, except crows, magpies, blackbirds, cowbirds, grackles, English sparrows and such other birds as may be designated by the Lieutenant Governor in Council, unless he is expressly authorized to do so by this Act or by a subsisting licence or permit issued to him pursuant to this Act.

"(2) Notwithstanding subsection (1), a person may, without such licence or permit, hunt, take, shoot at, wound or kill snowy owls, great horned owls and goshawks during the period from the first day of November in any year to the last day of March in the following year, both dates inclusive, unless with respect to any such period or any portion of any such period the Lieutenant Governor in Council by order declares that this subsection shall not apply during that period or portion.

"(3) Notwithstanding subsection (1) lbut otherwise subject to this Act and the regulations, an owner or occupant of any land outside a city, town, village or hamlet, actually domiciled and living upon any part of such land, may hunt, take, shoot at, "wound or kill game birds within the limits of such land without a licence or permit during open seasons."

Formerly, Section 10 read in part as follows:

“(1) Subject to subsection (2), no person shall hunt, take, shoot at, wound or kill any game bird or any other bird which is wild by nature and in a state of nature, except crows, magpies, snowy owls, great horned owls, goshawks, pigeon hawks, duck hawks, Cooper's hawks, sharp-shinned hawks, blackbirds, cowbirds, grackles, English sparrows, cormorants and such other birds as may be designated by the Lieutenant Governor in Council, unless he is expressly authorized to do so by this Act or by a subsisting licence or permit issued to him pursuant to this Act."

Subsection 3 of section 10a, which parmits the landowner to protect his stock and poultry against depredation by hawks and owls, reads as follows:

"(3) Northing in subsection (1) or (2) shall prevent 'a person from hunting, taking, shooting at, wounding or killing any wild animal or wild bird in a building in which poultry or domestic animals are kept or within six hundred feet from such building or from a hive where domestic bees are kept or for the purpose of protecting live stock or poultry on land owned or occupied by him." 